\title{
Effectiveness of Grading on Population Growth Performance for Giant Gourami (Osphronemus gourami) in Selection Program
}

\author{
Sularto $^{1}$, Lies Emmawati Hadie ${ }^{2 *}$, Rita Febrianti ${ }^{1}$, and Imron ${ }^{1}$ \\ ${ }^{1}$ Research Institute for Fish Breeding, 2 Sukamandi, Subang, West Java, Indonesia \\ ${ }^{2}$ Research Centre for Fisheries, 20 Ragunan Street, South Jakarta, Indonesia
}

\begin{abstract}
Selection programs applied to fish commodities can be done through some structured stages. The grading process is one of the critical stages of the selection program. Grading can be done by selecting a group of fish in a population that has the best growth performance. Fish groups that selection criteria for the next are maintained populations. The purpose of the study was to determine the effectiveness of grading on the growth of the gourami. This research conducted strains of giant ${ }^{1}$ gourami Jambi, Kalimantan, Majalengka, and Tasikmalaya strains.The first grading with fish body weight criteria was carried out by the time the gourami population was 11 months old, so it was obtained sub population in three sizes. Each strain is then nurtured separately. After each population months-old gourami, each individual was tagged, then maintained communally until 25 months old. Results of the experiment suggest that grading is apparently effective in affecting giant gourami growth significantly differences $(\mathrm{P}<$ 0.05). The implications of this research can be applied in the huge gourami selection program to produce superior strain.
\end{abstract}

\section{Introduction}

In the selection process to get the superior fish, cultivation activities are performed gradually following the rearing process to produce optimum growth. The selection process is done with the fish population gradient by taking fish groups with the best growth performance /fastest growth to a certain extent [1]. Selection activities are done at specific sizes and different for each fish type. Each cultivator has consideration or other reasons in determining the size or age of the fish to choose. The fish selection should be made on the size of consumption by the breeder. After obtaining a fish of choice with the desired character, labeling or tagging each fish is indispensable to ease the following process in the breeding program.

Giant gourami fish (Osphronemus gourami) has a growth pattern where males grow faster than females [2]. It takes a between family to process the selection. Another thing to consider in a giant gourami selection program is an environmental cultivation factor. As reported by [3] that aquaculture, ecological variables can affect fish growth performance throughout the production environment. The difference between ecological variables can induce a

*Corresponding author: mmlitbang@gmail.com 
phenomenon called genotype interaction by the environment. Therefore, to reduce bias in giant gourami selection by environmental factors, it needs to be carefully reckoned with both aspects. There is a possible change in ranking genotype performance in different environments, which is the best genotype in one production environment may not be the best in another production environment. As confirmed by [3], selection based on one environment can reduce genetic advantages in other production environments.

According to [4], the selection at a single nucleus station can lead to lower genetic acquisition than expected in other production environments at the time of genotypeenvironment interaction [5]. Genotype-environment interactions have different shapes: outplaying the entire environment and genetic variance heterogeneity [6]. Genetic improvements can potentially reduce various environmental impacts simultaneously, but this selective breeding aspect has not been explored much during this time in fish production [7]. In too high many species of fish, genetic response selection is due to increased commercial character heritability, high selection intensity, and high genetic variation [8]. Genetic improvements, obtained through a selection program, effectively produce cumulative changes in the animal population. One genetic improvement in fish performance is an expected benefit for the economy and suggests evaluating the environmental impact of genetic improvements by calculating ecological values.

The breeding program is expected to provide an essential boost to productivity [9]. However, the breeder is expected to produce fish seeds for cultivators with very different cultivation environment conditions. Hence, an efficient selection program for growth requires knowledge of genetic interactions and environmental. This research aims to know the effectiveness of grading in affecting the growth of giant gourami (O. gourami) to selection program.

\section{Material and methods}

\subsection{Experimental fish}

The research was conducted at Research Institute for Fish Breeding at Sukamandi, West Java, Indonesia, for 14 months. The ponds a $400 \mathrm{~m} 2$ and a $2000 \mathrm{~m} 2$ The giant gourami fish used originated from polulations : Jambi, Kalimantan, Majalengka and Tasikmalaya. Test fish used aged 11 months with an average eight of $300 \mathrm{~g}$ and maintained in the earthen ponds until 25 months. Three groups of gourami based on size class in each population were kept in separate ponds. After 15 months, they were tagged with a micro-chip and then kept in the same pond until they were 25 months old.

All four populations were initially been nurtured in one pond, each population separated by a net. Grading is done in 11 month old giant gourami population based on body weight, so grouped each to three grades: grade $1=10 \%$ best weight each population; grade $2=$ above average weight \pm 1 deviation standards; grade 3: average weight \pm 1 deviation standards. Three groups of fish with three-grade giant gourami were maintained in a separate pond. After 15 months, each is micro-chip tagged and then held in the same pond communally until 25 months old.

\subsection{Growth performance}

Fish growth observations were made every two months to adjust the feeding, and individual weights were weighed in all populations 6 times during the search for personal growth pattern observation. The feed is a pellet with protein levels $30.0-33.0 \%$. Feeding rate of feed were $3.0 \%$, and twice day ${ }^{-1}$. 
Water quality observation is done every two months. Water quality parameters observed include: temperature $\left({ }^{\circ} \mathrm{C}\right)$, dissolved oxygen $\left(\mathrm{mgL}^{-1}\right)$, also $\mathrm{pH}$ based on water quality checker, and ammonia $\left(\mathrm{mgL}^{-1}\right)$, nitrite $\left(\mathrm{mg}^{\mathrm{L}-1}\right)$, and nitrate $\left(\mathrm{mg}^{\mathrm{L}-1}\right)$ ) were observed by spectrophotometry (SNI 06-6989-30-2005).

\subsection{Data analysis}

The treatment effect on test parameters was analyzed using two-way ANOVA at a 95\% confidence interval. The Tukey HSD test with SPSS version 16 was conducted when resulted in a significant difference among the treatment.

\section{Results}

Research results show a significant giant gourami growth difference in three levels of grading weights in four different trains $(\mathrm{P}<0.05)$. But there is no significant difference in weight growth between strains $(\mathrm{P}>0.05)$. The average giant gourami weight growth at the end of research can be seen in Table 1 .

Table 1. Average weight \pm SD $(\mathrm{g})$ giant gourami of Jambi, Kalimantan, Majalengka, and Tasikmalaya strain in three grading of final experiment.

\begin{tabular}{|l|c|c|}
\hline Originated from & Grade & Average weight \pm SD $(g)$ \\
\hline Jambi & 1 & $2280 \pm 318.5$ \\
& 2 & $2070 \pm 314.0$ \\
& 3 & $1950 \pm 341.0$ \\
\hline Kalimantan & 1 & $2512 \pm 287.1$ \\
& 2 & $1990 \pm 222.3$ \\
& 3 & $2040 \pm 459.5$ \\
\hline Majalengka & 1 & $2426 \pm 411.4$ \\
& 2 & $2123 \pm 359.6$ \\
& 3 & $1957 \pm 260.8$ \\
\hline Tasikmalaya & 1 & $2413 \pm 447.2$ \\
& 2 & $2110 \pm 396.7$ \\
& 3 & $1840 \pm 392.0$ \\
\hline
\end{tabular}

Profile of growth on giant gourami was showed in Fig. 1.
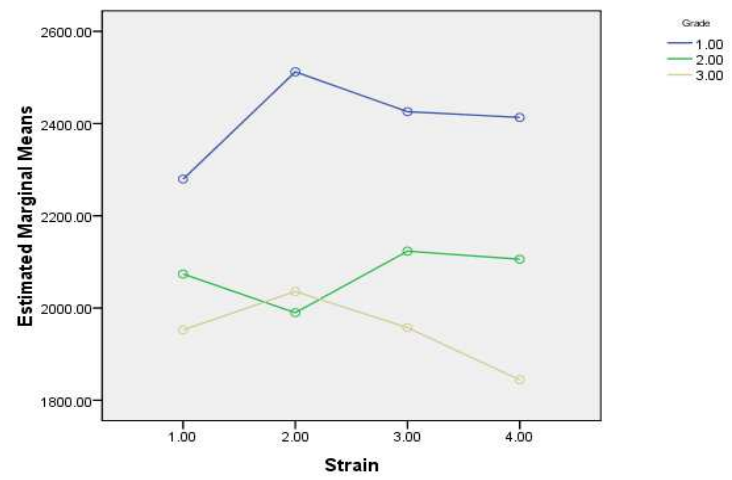

populations (strain) from Jambi, Kalimantan, Majalengka, and Tasikmalaya. 
Analysis of variance showed a significant intercept on the growth of giant gourami weight. The value of coefficient determination was reached 0.265 (Table 2).

Table 2. Analysis of variance for an individual bodyweight of four varieties of giant gourami, which were grown up for 14 months.

\begin{tabular}{|l|c|c|c|c|c|}
\hline Source of variance & Sum of square & $\begin{array}{c}\text { Degree } \\
\text { of free }\end{array}$ & $\begin{array}{c}\text { Mean of } \\
\text { square }\end{array}$ & $\mathrm{F}$ & Significance \\
\hline $\begin{array}{l}\text { Originated } \\
\text { population }\end{array}$ & 167707.133 & 3 & 55902.378 & 0.431 & 0.731 \\
\hline Grade & 6776804.465 & 2 & 3388402.233 & $26.099^{*}$ & 0.00 \\
\hline $\begin{array}{l}\text { Originated } \\
\text { population*Grade }\end{array}$ & 619268.003 & 6 & 103211.334 & 0.795 & 0.575 \\
\hline Intercept & $7.185 \mathrm{E} 8$ & 1 & $7.185 \mathrm{E} 8$ & $5.534 \mathrm{E} 3 *$ & 0.00 \\
\hline
\end{tabular}

R squared $=0.265$ (Adjusted $\mathrm{R}$ squared $=0.217$ )

Water quality was observed during the experiment can be seen in Table 3 .

Table 3. Water quality of ponds size for $400 \mathrm{~m}^{2}$ and $2000 \mathrm{~m}^{2}$ include temperature $\left({ }^{\circ} \mathrm{C}\right), \mathrm{pH}, \mathrm{DO}(\mathrm{mg}$ $\left.\mathrm{L}^{-1}\right)$, ammonia $\left(\mathrm{mg} \mathrm{L}^{-1}\right)$, nitrite $\left(\mathrm{mg} \mathrm{L}^{-1}\right)$, and nitrate $\left(\mathrm{mg} \mathrm{L}^{-1}\right)$ in giant gourami for 14 months.

\begin{tabular}{|l|l|l|l|l|l|l|}
\hline $\begin{array}{c}\text { Ponds size } \\
\left(\mathrm{m}^{2}\right)\end{array}$ & \multicolumn{6}{|c|}{ Parameter of water quality } \\
\hline & $\begin{array}{c}\text { Temperature } \\
\left({ }^{\circ} \mathrm{C}\right)\end{array}$ & $\mathrm{pH}$ & $\begin{array}{c}\text { DO } \\
\left(\mathrm{mg} \mathrm{L}^{-1}\right)\end{array}$ & $\begin{array}{c}\text { Amonnia } \\
\left(\mathrm{mg} \mathrm{L}^{-1}\right)\end{array}$ & $\begin{array}{c}\text { Nitrite } \\
\left(\mathrm{mg} \mathrm{L}^{-1}\right)\end{array}$ & $\begin{array}{c}\text { Nitrate } \\
\left(\mathrm{mg} \mathrm{L}^{-1}\right)\end{array}$ \\
\hline 400 & $25.7-33.9$ & $\begin{array}{l}7.0- \\
8.29\end{array}$ & $0.6-6.33$ & $0.381-$ & $0.006-$ & $0.16-1.19$ \\
& & & 1.79 & 1.66 & \\
\hline 2000 & $26.6-33.6$ & $\begin{array}{l}6.62- \\
7.3\end{array}$ & $0.9-5.28$ & $0.086-$ & $0.02-$ & - \\
& & & 0.119 & 0.053 & \\
\hline
\end{tabular}

\section{Discussions}

Results of the research suggest a significant giant gourami growth difference in three levels of grading weights in four different strains $(\mathrm{P}<0.05)$. The effect of this grading process gives the best growth result in the first grade. The average weight of giant gourami was 2280-2512 $\mathrm{g}$ (Table 1). This result shows the genetic potential of the first grade that can be expressed optimally. The selection at $10 \%$ of the best weights of the total giant gourami population in this research has indeed proven to produce the best growth and considerable diversity of phenotypes. Majalengka, Kalimantan, and Tasikmalaya's enormous gourami strain produce a better subpopulation compared to Jambi's relatively slower strain of weight gain.

The grading influences can also be known based on plot diagrams of each gourami strain in the first, second, and third grades. Giant gourami growth in first grade showed that the sub populations were far above second and third grade sub populations. This plot diagram shows the interaction between strain and presence of quality, it is proven that the lines drawn are not aligned (Fig. 1). This is an indication of the effect of interaction grading and giant gourami on different strains.

In the maintenance phase in different environments, there is a change in growth pattern, which higher grade shows better growth. Figure 1 shows the presence of genetic interaction with the environment. If noticed more carefully, this is thought to be more caused by genetic factors of fish that have better genetic quality will show better growth performance, which was previously not expressed when maintained in a less optimum environment. The value of 
this environment is said that for breeding programs is expected to provide a significant increase of value in productivity framework, as in all fish species $[10,11]$ because of heritability of growth properties ranges from medium to high in this species [12] Genetic repair potentially reduces various environmental impacts [8]. Genetic repair obtained through a selection program is an excellent way to produce changes cumulative changes in the animal population. The genetic increase can be seen in fish growth performance is expected to profit economically [7;13]. According to [11], genotype-environment interaction occurs especially when genotype and environment variations are large enough. Genotype - environment: interaction increases with increasing genetic distance and increasing environmental differences.

Results of analysis of variance were showed that a significant intercept in the growth of giant gourami weights. This indicates that there can be a change in the value of insignificant growth without the effect of gourami strain.

The determination coefficient value reached 0.265 , the result of this analysis shows that the effect of originated population and grading types have relatively low correlations (Table 2). This means that the originated population can be ignored in producing a relatively fast gourami population in growth.

Maintenance shows better growth communal gourami than separately. This is evident with a change in environmental maintenance conditions that significantly affect the metabolism performance of gourami fish. There is more continuous water change at a pond of $2000 \mathrm{~m} 2$, so the water quality is relatively better. This has a good effect on fish appetite. Gourami has an additional breathing tool, so the gourami fish can survive on low oxygen levels.

Nevertheless, it turns out that giant gourami grows better in high oxygen waters. In general aquaculture activities, the amount of dissolved oxygen in the water is a limiting factor that significantly influences productivity. Dissolved oxygen significantly affects fish appetite, growth, and metabolic rate [14]. High oxygen availability will help the fish show the best performance, while low oxygen content will hamper growth and metabolic activity.

Water quality parameters during the research are shown in Table 3 . There is a difference between water quality in a pond of $400 \mathrm{~m}^{2}$ and $2000 \mathrm{~m}^{2}$. Oxygen content in a pond of $400 \mathrm{~m}^{2}$ dissolved oxygen content at night until the early morning of $0.5 \mathrm{mg} \mathrm{L}^{-1}$. Oxygen condition under $1 \mathrm{mg} \mathrm{L}^{-1}$ is suitable to support the growth of fish in general. Based on Table 3 there is a difference between water quality between $400 \mathrm{~m}^{2}$ pond and $2000 \mathrm{~m}^{2}$ pond. In a pond of 400 $\mathrm{m}^{2}$ the water quality is relatively more comprehensive. In other words, more volatile than $2000 \mathrm{~m}^{2}$ ponds, especially for dissolved oxygen and ammonia content. $400 \mathrm{~m}^{2}$ pond the dissolved oxygen content in the morning is very low $0.6 \mathrm{mgL}^{-1}$, while at $2000 \mathrm{~m}^{2}$ pond reaches $0.9 \mathrm{mgL}^{-1}$.

The ammonia content of $400 \mathrm{~m}^{2}$ pond in the relatively high dry season is $1.793 \mathrm{mgL}^{-1}$, which is due to a lack of income or water change, thus the accumulation of remaining feed and fish dirt will result in increased ammonia levels. This condition is due to fish cultivation waste which is a result of metabolic activity containing ammonia. Fish issued 80-90\% ammonia (N-inorganic) through osmoregulation process, while from feces and urine around $10-20 \%$ of total nitrogen [15]. The condition causes reduced appetite, thus impacting the hamper of fish growth. The accumulation of ammonia in cultivation media causes declining water quality, failing in fish cultivation production [16]. Ammonia's expansion in cultivation media is one of the causes of decreasing water quality that can fail in fish cultivation production. The body cell wall is relatively impermeable to ammonia $\left(\mathrm{NH}^{+}\right)$, but molecular ammonia $\left(\mathrm{NH}_{3}\right)$ can easily diffuse through a concentration gradient and tissue barrier. Therefore, ammonia is potentially poisonous for fish. Ammonia harms the brain that's why nerve symptoms occur in ammonia toxicity to fish [17]. According to [18] giant gourami can still live and grow on nitrite content of $0.1578-1.6635 \mathrm{mgL}^{-1}$, although affirmed whose nitrite 
limit value for cultivation is less than $1 \mathrm{mgL}^{-1}$. According to [18 ] reports ammonia 1.78 the maintenance $\mathrm{mg} \mathrm{L}^{-1}$ on giant gourami seed, the fish will die totally in the 52 nd hour. It is reported by [19] that reducing ammonia content in maintenance media can increase appetite and can increase the growth of fish.

\section{Conclusion}

Results of the experiment suggest that grading effectively affects the average weight of giant gourami significantly differences $(\mathrm{P}<0.05)$. The implications of this research can be applied in the giant gourami selection program to produce superior strain.

\section{Acknowledgement}

The authors would like to thank the Head of the office at Research Institute for Fish Breeding for financing this research by government budget.

\section{References}

1. D. Tave, Selective breeding programmes or medium-sized fish farms (FAO, Rome, 1995).

2. Sularto, R. Febrianti, Haryanto, J. Aqua. Res. 11, 1 (2016)

3. R. Bangera, M. Tale, K. Drangsholt, H.M. Nielsen, P. Sae-Lim, J. Ødegård, V. Puvanendran, Ø J. Hansen, A. Mortensen, J. Mar. Sci. Eng. 3 (2015)

4. P.S. Lim, A. Kause, H.A. Mulder, K.E. Martin, A.J. Barfoot, J. E. Parsons, J. Davidson, C. E. Rexroad III, J. A. M. van Arendonk, H. Komen, J. Anim. Sci. 91 (2014)

5. H.A. Mulder, P. Bijma, J. Anim. Sci. 83, 1 (2005)

6. D.S. Falconer, T.F.C. Mackay. Introduction to quantitative genetics (Longman Group, Harlow, 1996)

7. M. Besson, J. Aubin, H. Komen, M. Poelman, E. Quillet, M. Vandeputte, J.A.M. Van Arendonk, I.J.M. De Boer, J. Clean. Prod. 116, 100-109 (2016)

8. T. Gjedrem, N. Robinson, M. Rye, Aquac. 350-353, 117-129 (2012)

9. Dupont-Nivet, M., B. Karahan-Nommb, A. Vergnetc, O. Merdya, P. Haffrayd, H. Chavannee, B. Chatainc, M. Vandeputtea, Aquac. 306, 365 - 368 (2010)

10. T. Gjedrem, J. Thodesen. Selection in selection and breeding programs in aquaculture. (Springer Netherlands, Dordrecht, 2005)

11. E. Saillant, M. Dupont-Nivet, P. Haffray, B. Chatain, Aquac. 254, 139-147 (2006)

12. R.W. Ponzoni, N.H. Nguyen, H.L. Khaw, Aquac. 269, 187 - 199 (2007)

13. A.F.M. El-Sayed. Tilapia Culture (CABI Publishing, Wallingford, 2006)

14. A. Dmitry. Postgraduate Thesis, Mikkeli (NZ): Mikkeli University (2013)

15. Sumoharjo, Postgraduate, Bogor (ID): Institut Pertanian Bogor, (2010)

16. O.Wijaya, B. Rahardja ,S. Prayogo, J. Sci. Mar. Fish. 6, 1 (2014)

17. R. Febrianti, N. Listiowati, Sularto, National Fisheries Conference, (2016)

18. R. Febrianti, S. Sularto, S.Suharyanto, Fishery High School, (2016)

19. S. Wahyuningsih, A. Mei Gitarama, Indones. Sci. J. 5, 2 (2020) 